\title{
O NINHO DO JAPU: PERSPECTIVISMO, GÊNERO E RELAÇÕES INTERESPÉCIES AIRO-PAI
}

\author{
Luisa Elvira Belaunde (D)
}




\section{RESUMO}

Este artigo aborda a conexão entre perspectivismo e gênero a partir da etnografia airo-pai da linguagem xamânica dos seres celestes, bem como as relações interespecíficas que a atravessam. Examino as conexões entre perspectivismo, totemismo e gênero presentes nos cantos da puberdade masculina e na exegese indígena desses cantos. Argumento que o gênero surge de múltiplas relações interespecíficas e se expressa cotidiana e ritualmente, especialmente nos ensinos xamânicos da puberdade masculina, que colocam os jovens na posição de filhotes de pássaros em seus ninhos. Entre os Airo-Pai, ser capturado pela perspectiva do outro nem sempre aciona a predação. É necessário considerar a criação e a temporalidade como vetores da percepção dos seres celestes para compreender o gênero como perspectiva.

\section{Palavras-chave: gênero na Amazônia; perspectivismo; relações interespécies; puberdade masculina, Secoya.}

\section{THE YAPU'S NEST: PERSPECTIVISM, GENDER AND INTERSPECIES RELATIONS AIRO PAI}

\section{ABSTRACT}

The paper discusses the connection between perspectivism and gender from the Airo Pai ethnography of the shamanic language of celestial beings and the interspecific relations that cross it. I examine the connections between perspectivism, totemism and gender present in the shamanic chants of male puberty and in the indigenous exegesis of these chants. I argue that gender arises from multiple interspecific relations and it is expressed daily and ritually, especially in the shamanic teachings of male puberty that place young boys in the position of baby birds in their nests. Among the Airo Pai, being caught by the perspective of another does not always trigger predation. It is necessary to consider creation and temporality as vectors of the perception of celestial beings to understand gender as a perspective.

Keywords: Amazonian gender; perspectivism; interspecific relations; male puberty; Secoya.

\section{EL NIDO DEL YAPÚ: PERSPECTIVISMO, GÉNERO Y RELACIONES INTERESPECÍFICAS AIRO PAI}

Este artículo aborda las conexiones entre perspectivismo y género desde la etnografía Airo Pai del lenguaje chamánico de los seres celestiales y las relaciones interespecíficas que lo atraviesan. Examino las conexiones entre perspectivismo, totemismo y género presentes en los cantos de la pubertad masculina y en la exégesis indígena de estos cantos. Sostengo que el género surge de múltiples relaciones interespecíficas y tiene una expresión cotidiana y ritual, especialmente en las enseñanzas chamánicas de la pubertad masculina que colocan a los jóvenes en la posición de crías de pájaros en sus nidos. Entre los Airo Pai, ser atrapado por la perspectiva del otro no siempre acciona la depredación. La creación y la temporalidad deben considerarse como vectores de la percepción de los seres celestiales para comprender el género como perspectiva.

Palabras clave: Género en la Amazonia; perspectivismo; relaciones interespecíficas; pubertad masculina; Secoya. 


\section{INTRODUÇÃO}

Este artigo aborda a conexão entre perspectivismo e gênero a partir do estudo da linguagem xamânica e das relações interespecíficas que a atravessam. A base da argumentação vem de um ensaio que escrevi em 1992, quando estava terminando minha pesquisa de doutorado com os Airo-Pai (também chamados Secoya), um povo da família linguística tucano ocidental, da região da tríplice fronteira entre Peru, Equador e Colômbia, nas bacias dos rios Napo e Putumayo ${ }^{1}$. Originalmente, o ensaio chamava-se "Como os mortos veem os vivos: xamanismo e gênero entre os Airo-Pai”, mas alguns colegas na Inglaterra, onde eu estudava, reagiram dizendo que, para a antropologia britânica, este título não fazia sentido nenhum. A antropologia social estuda a maneira como os vivos percebem os mortos, e não o contrário, me disseram. Então, no título final, "Papagaios e japus: a estética das relações de gênero entre os Airo-Pai”, publicado em 1994, tirei os mortos e coloquei as aves que eles veem quando olham para os vivos (Belaunde 1994).

No ensaio, argumentei, de acordo com o pensamento airo-pai, que quando os seres celestiais associados à ressurreição dos mortos olham para mulheres e homens vivos, eles veem "filhotes" (si) de pássaros de duas espécies diferentes: as mulheres são hue'ecosi, "filhotes de papagaio" (Amazona sp.); os homens são umusi, "filhotes de japu" (Icteridus sp.). Essa percepção de sua cosmo-ornitologia repercutia na organização do parentesco e da parentalidade, na medida em que uma estética social associada à reprodução paralela surgia como extensão do dimorfismo de gênero, concebido em termos de uma diferença entre espécies de pássaros. Do ponto de vista dos seres celestiais, mulheres e homens são filhotes de pássaros que se reproduzem separadamente. Embora ambos pássaros sejam muito gregários, eles têm hábitos reprodutivos, alimentares e defensivos contrastantes.

Neste artigo, proponho me debruçar sobre essas e outras relações interespécies que atravessam o gênero airo-pai, em particular a masculinidade. Meu intuito é também indagar se podemos falar em perspectivismo de gênero e quais são as consequências de ser visto como filhote pelos seres celestiais. Qual é a relação entre a posição do filhote no xamanismo curandeiro e a posição da presa, enfatizada nas teorias do perspectivismo sobre a caça? Entre os Airo-Pai, a predação também

1 No Equador e no Peru, eles são oficialmente conhecidos pelas instituições do Estado como Secoya. Airo pai (gente desta floresta) é a autodenominação que eles usaram comigo, no tempo do meu trabalho de campo de doutorado. Atualmente, no Equador e no Peru, eles também usam a autodenominação Siekopai (gente arco-íris). A população atual dos Airo-Pai no Peru é de, aproximadamente, 600 pessoas. 
é, sem dúvida, um eixo central de seu pensamento, de sua organização social e sua cosmologia, mas, na minha opinião, não é o único. Ser capturado pela perspectiva do outro nem sempre se refere a um dilema entre comer ou ser comido. É necessário abordar outros dilemas relacionais da percepção para tratar a diferença de gênero como uma perspectiva e entender as implicações mais amplas dos rituais de puberdade nas cosmologias e ontologias ameríndias. A questão que quero colocar neste artigo é, então, a seguinte: é possível desenvolver para a perspectiva ameríndia uma análise que escape à preponderância da predação ontológica, passando a englobar outros vetores de diferença?

Como seus vizinhos Siona, no Equador e na Colômbia (Langdon 1979, 2014; Vickers 1989), os Airo-Pai tinham reputação de serem grandes xamãs bebedores de yaje (Banisteriopsis caapi). Quando eu cheguei nas suas comunidades, no Peru, em 1988, a adesão ao culto evangélico pentecostal estava começando a se espalhar. Eu nunca participei de uma sessão de ingestão de yaje, porém, observei que as noções que organizavam seu xamanismo curandeiro permeavam o dia a dia. Todos os homens com idade acima de 30 anos haviam sido iniciados no xamanismo do yaje durante a puberdade, e as mulheres haviam sido formadas pelos rituais da menarca. Ambos os gêneros haviam sido preparados para morar em aldeias onde o yaje uncuquë (bebedor de yaje) era o mediador das relações entre seus parentes próximos e os seres do cosmos. Em todas as casas, havia xamãs curandeiros que, até alguns anos atrás, se reuniam durante as sessões coletivas de ingestão de yaje para chamar os seres celestiais, conversar com eles por meio de cantos e pedir ensinamentos ou plantas medicinais. Os homens particularmente conhecedores eram considerados verdadeiros geradores de vida. O bebedor de yaje que liderava as sessões de cantos "fazia as pessoas viverem", eles me explicaram, e por isso ele era chamado inti paíquë, "aquele que vive" ou "o vivente" (Payaguaje 1990; Cipolletti 1988a, 1988b, 2008; Moya 1992).

Três homens iniciados no xamanismo, Cesario Belisario Piaguaje Payaguaje, Liberato Coquinche Levy e Oscar Vasquez Macanilla, estiveram especialmente próximos e me guiaram, com grande generosidade, durante a minha pesquisa sobre este assunto. Além de me acolherem nas suas famílias, eles me contaram muitos "relatos dos antigos" (aірё сосиa) e cantaram para meu gravador os cantos xamânicos que aprenderam durante o ritual de puberdade. Eles gostavam de falar das suas experiências xamânicas e de cantar para meu gravador, pois, como disseram, eram cantos de cura e de ensinamento. Quando um deles gravava um relato ou um canto para mim, eu 
pedia que traduzisse livremente e na mesma hora as suas palavras para o espanhol. Essa metodologia de registro e tradução informal me permitiu acessar uma riqueza de informação surpreendente, pois, além de produzirem traduções próprias, eles me forneceram espontaneamente explicações sobre as conexões entre humanos e não humanos tecidas pelo xamanismo.

\section{PERSPECTIVISMO, GÊNERO E TOTEMISMO}

Nos últimos anos, o estudo das relações interespécies tem suscitado uma dinâmica controversa, rejeitando os automatismos da ciência nas fronteiras entre humanos e não humanos e destacando a incidência de cosmologias e ontologias em todas as formas de conhecimento e ação política sobre os seres vivos (Haraway 2003; Ingold 2011; De la Cadena 2015). Cabe notar que, em 1992, quando escrevi o ensaio mencionado no início deste artigo (Belaunde 1994), esse movimento de abertura para outras formas de ser e de saber era incipiente. A decisão de levar a sério a existência dos sujeitos que povoam as cosmologias ameríndias e a transformabilidade dos multiversos xamânicos eram algo incomum fora de um pequeno círculo de pesquisadores. $\mathrm{Na}$ etnologia indígena, as propostas pioneiras de Overing (1990) sublinharam a necessidade de abordar as cosmologias amazônicas como filosofia e criação de mundos, não como crença; mas o estudo da perspectiva e dos cantos xamânicos ainda estava em seu começo (Brown 1985; Descola 1986; Århem 1993). As teorias perspectivistas de Lima (1996) e de Viveiros de Castro (1996) não haviam sido publicadas, e os instrumentos conceituais disponíveis para analisar as modalidades de percepção e expressão ameríndias estavam ancorados no simbolismo.

Nesse contexto, analisei a etnografia airopai dos filhotes de aves a partir dos conceitos de simbolismo linguístico, por exemplo, tomando emprestada a noção de "metáforas cosmológicas" cunhada por Crocker (1977), em seu estudo sobre o parentesco Bororo. Também argumentei que, quando essas figuras dos filhotes de aves apareciam nos cantos xamânicos airo-pai, eles agiam à maneira de "palavras tortas" (Townsley 1993), evitando nomear as coisas com as palavras cotidianas e produzindo "duplos" miméticos (Taussig 1993), que visavam garantir a eficácia ritual do canto. No entanto, insisti que não eram apenas figuras da linguagem e instrumentos de performaticidade ritual, pois, para os Airo-Pai, o cerne da questão estava na percepção dos seres celestiais quando olhavam para os vivos. Essa percepção apresentava implicações importantes na existência de pessoas e de seres do cosmos.

Além disso, argumentei que, entre todos os 
hábitos assinalados nas explicações airo-pai sobre o comportamento dos pássaros, a forma de aninhar dessas aves era o aspecto mais salientado em suas exegeses espontâneas quanto aos relatos e cantos xamânicos. Como Cesario me explicou, com sua clareza característica, quando os seres celestiais olham para as mulheres "nesta terra" (iye yeja), eles veem filhotes de papagaios, afinal "mulheres e papagaios se aninham dentro das cavidades das árvores feitas pelo pica-pau”; mas, quando eles olham para os homens, veem filhotes de japus, pois "os homens, como os japus, tecem belos ninhos para criar seus pequenos". A analogia entre os hábitos reprodutivos dos gêneros e seus pássaros respectivos era, portanto, a chave para entender o olhar dos seres celestiais, que, por um lado, eclipsava a diferença entre humanos e não humanos e, por outro lado, visibilizava a diferença entre os gêneros humanos. No olhar dos seres celestiais, os homens e as mulheres vivos eram filhotes de pássaros diferentes, pois tinham ninhos distintos. Com o característico humor airo-pai, don Cesario sorria ironicamente quando refletia sobre o fato de que "eles nos veem como pássaros, mas nós, aqui, nos vemos como gente" (Belaunde 2001:93).

Quando os textos de Lima (1996) e Viveiros de Castro (1996) foram publicados, ficou claro para mim que as noções de perspectiva poderiam ser utilizadas para pensar a etnografia airo-pai, mas também observei algumas ausências que me chamaram atenção: começando pelo fato de que o gênero e a criação de filhotes não faziam parte dos seus argumentos. Apesar das diferenças das suas abordagens, eles coincidiam em destacar as relações entre presa e predador como princípio ontológico da multiplicidade da percepção. Posteriormente, Lima (2005), desenvolveu um inovador estudo sobre a criação, o gênero e a perspectiva do caium entre os Yudjá, mas durante vários anos a questão de gênero continuou ausente em grande parte da etnologia indígena produzida no Brasil. Quando, em 2007, Eduardo Viveiros de Castro me concedeu uma entrevista, aproveitei para lhe perguntar por que, em sua opinião, o gênero não estava entre os tópicos abordados. Sua resposta foi esclarecedora:
Esse é o seu tema... Cabe a você desenvolvê-lo. Creio que a focalização quase exclusiva, por parte dos trabalhos anteriores sobre o perspectivismo, nas relações entre as espécies (animais e outras), tendeu a obscurecer a relação entre os gêneros - se permite o trocadilho... Mas, justamente, o interessante de seu trabalho com os Airo-Pai é que a segunda - a relação entre os gêneros humanos - é conceitualizada nos termos de diferenças entre espécies animais. Espécies do mesmo "gênero", diga-se de passagem, já que espécies de pássaros. Interessantemente, os Araweté me diziam que os seus deuses, os Maï, viam os humanos como jabutis (de ambos os gêneros!), animais que vêm a ser um dos principais alimentos dos Araweté eles mesmos (Viveiros de Castro \& Belaunde 2007:126-127). 
Enfatizo que, em sua resposta, Viveiros de Castro não dizia que o gênero era um conceito irrelevante na Amazônia, como é o caso da declaração, ao meu ver precipitada, de Descola (2001), aceita por muitos antropólogos sem grandes questionamentos. Esta resposta recomendava abordar a etnografia airo-pai levando-se em consideração as correlações que ele observou com perspicácia. Sua sugestão foi que, neste caso etnográfico, a diferença de gênero fazia parte de uma relação mais abrangente de homologia entre duas séries de diferenças: uma série social de diferenças entre os gêneros da mesma espécie (humana) e outra série natural de diferenças entre espécies do mesmo gênero (biológico), as aves. As relações entre os gêneros e os filhotes de aves poderiam, portanto, ser analisadas sob a luz do totemismo. Como argumentou Lévi-Strauss (1962:111), em sua releitura estruturalista do totemismo, a homologia entre séries de diferenças define a organização social totêmica, pois "não são as semelhanças, mas as diferenças que se assemelham”. Embora a organização totêmica opere principalmente no nível coletivo, entre clãs e grupos exogâmicos, por exemplo, seu estudo também inclui alguns casos de totemismo de acordo com o gênero das pessoas. Por exemplo, Lévi-Strauss menciona o "totemismo sexual" observado entre os povos do sul da Austrália, segundo o qual homens e mulheres atuavam como grupos opostos, quando se tratava de defender seus respectivos totens.

Antes de analisar as possíveis ressonâncias totêmicas do gênero entre os Airo-Pai, apresento as principais ideias do seu xamanismo curandeiro e os ensinamentos xamânicos na puberdade masculina. Cabe notar que os quelônios de ambos os sexos, vistos pelas divindades Araweté quando olham os vivos, são uma das comidas favoritas dos Araweté. Essa visão é consistente, na minha opinião, com o destaque da predação como princípio dinâmico da cosmologia e da ontologia Araweté. Os papagaios e os japus vistos pelos seres celestiais airo-pai, no entanto, não são alimentos favoritos em suas comunidades. Eles se destacam, principalmente, pelas suas formas de aninhar.

\section{XAMANISMO E ALEGRIA}

Como mencionei, quando eu cheguei às comunidades airo-pai, em 1988, a adesão ao culto evangélico pentecostal estava crescendo, e vários homens estavam considerando deixar de tomar yaje. Curiosamente, longe de invalidar ou descartar as concepções sobre os seres celestiais, a adesão ao pentecostalismo dava continuidade a essas concepções em vários aspectos. O culto evangélico era considerado, pelos Airo-Pai, como uma maneira de realizar um ideal ético e estético ancestral, tipificado na expressão e no ensino 
do "viver bem" (deoyerepa paiye), notadamente no contexto violento da colonização da tríplice fronteira entre Peru, Colômbia e Equador, marcado pelas doenças trazidas pelos colonos, pela produção e pelo comércio ilegal de cocaína e pelo enfrentamento entre grupos armados. A rejeição do yaje não era uma imposição dos evangélicos totalmente alheia aos questionamentos airo-pai, pois os poderes conferidos pela planta sempre foram considerados ambivalentes. Era comum a ideia de que a morte dos parentes era causada pelos próprios xamãs airo-pai, incapazes de controlar os seus poderes (Belaunde 2000a, 2000b).

Além disso, também permanecia usual o consumo de outras plantas do xamanismo que eram consideradas necessárias para se sobrepor diariamente à preguiça, como o yoco (Paullinia yoco), um cipó silvestre com propriedades energizantes e consumido diariamente para que o dia fosse iniciado com boa disposição. Ainda que o yoco fosse intimamente associado ao yaje, e também fosse uma planta que precisava ser usada com cuidado, seus efeitos energizantes eram considerados maiores do que seus possíveis efeitos destrutivos. A procura do "viver bem" começava de madrugada, quando, em cada casa, os homens acordavam para tomar yoco e fazer fio de tucum (Astrocaryum chambira). O fio era feito enquanto se esperava o sol raiar, e era utilizado pelos homens durante o dia, para tecer finas redes. Mas sem yoco, eles me explicaram, não sentiam ânimo de trabalhar. De acordo com o pensamento airo-pai, o yoco era uma planta que interagia intersubjetivamente com as pessoas. Eles me diziam que ela "joga fora a preguiça" e "dá conselhos como um pai", levando as pessoas a trabalharem por decisão própria, de acordo com os aconselhamentos recebidos das plantas e dos ancestrais. Diariamente, observei os homens acordarem primeiro e irem fazer o fio. Suas esposas e crianças acordavam uma ou duas horas depois, e sentavam-se juntos. Os casais passavam esse tempo de intimidade esperando e contando seus sonhos, planejando o dia e aconselhando seus filhos para eles aprenderem a "pensar" (cuatsaye) por si mesmos, com base na escuta e na memória desses aconselhamentos guardados em seus "corações" (joyo). Acordar primeiro e fazer fio de tucum eram consideradas atividades masculinas por excelência, pois o homem, como o japu, era tecedor e madrugador. Quando um homem acordava tarde, ele era alvo de piadas, por ter se tornado papagaio (Belaunde \& Echeverri 2008a, 2008b).

Eu nunca assisti uma sessão de yaje, porém a ideia de que mulheres e homens "nesta terra" (iye yeja) eram vistos pelos seres celestiais como filhotes de pássaros era algo conhecido por todos, pelo menos no nível de conhecimento que eles 
compartilhavam abertamente comigo. Era algo como o 'abc' do xamanismo, que permeava seu dia a dia. Meu aprendizado desses conceitos foi possível graças à convivência diária com os AiroPai, durante a qual fui aprendendo o pai cocua, a língua airo-pai, graças às explicações em espanhol e às traduções que eles me ofereciam, muitas vezes espontaneamente.

Durante meu trabalho de campo, observei que, no dia a dia, as expressões "filhote do papagaio" e "filhote do japu" eram usadas para referir-se e dirigir-se aos gêneros de maneira galante. A noção de filhote $(s i)$ se aplicava aos humanos e não humanos, como os pintinhos e os brotos, e seu sentido enfatizava a pequenez e a vulnerabilidade, mas também o fato de estarem crescendo, se fortalecendo e cheios de alegria. O principal alvo dessas expressões eram os jovens, de ambos os gêneros. Por exemplo, quando um grupo de meninas lavava roupas na beira do rio, os homens que passavam por elas as chamavam de "filhotes de papagaio". Quando um bom pescador passava pela porta da casa, as mulheres o chamavam de "filhote de japu".

Além de serem chamados de filhotes de pássaros, os jovens também eram chamados de crias desses pássaros, no sentido de serem criados pelas aves. Essa ideia era expressada na palavra joya (joyaë, no feminino, e joyao, no masculino), que significa "ser criado por alguém". As mulheres eram hue'e co joyao ("criadas pelo papagaio") e os homens uтu joyaë ("criados pelo japu"). As duas expressões, tanto filhote quanto criado, sublinhavam a beleza (deoquë) de ambos os gêneros, entendida de uma maneira ampla. A palavra deoquë era traduzida para o espanhol pelos Airo-Pai de várias maneiras, como "belo", "bom”, "saudável”, "útil”; ao longo da minha permanência nas suas comunidades, compreendi que deoquë era tudo aquilo que contribuía para alcançar o objetivo de se "viver bem" (deoyerpa paiye). Por sua vez, "viver bem" era sinônimo de "alegrar-se" (sihuaye). Nesse sentido, a alegria não era considerada uma qualidade dada, mas um fazer diário, algo que deveria ser produzido. O corpo feminino e masculino, sem preguiça, robusto, limpo, perfumado, adornado com colares e pintado, era o considerado belo. Além da aparência física, era apreciada a capacidade das pessoas, sua diligência e sua habilidade de gerar alegria. Uma boa oleira e cozinheira era uma "mulher bonita" (deoco nomio). Um bom tecelão de redes e caçador era um "homem bonito" (deoquë ëmë). Mas não bastava não ter preguiça ou produzir para ser considerado bonito, sendo importante o fazer voluntariamente, com independência e generosidade. A beleza se referia tanto aos corpos habilidosos quanto aos afetos que "faziam as 
pessoas se alegrarem” (Belaunde 2001:94).

Essas noções sobre a criação de pessoas belas permaneciam plenamente vigentes, apesar do abandono da ingestão de yaje. O processo de aprendizado do pensamento pessoal era concebido em termos causais: "fazer escutar", "fazer pensar", "fazer comer", "fazer produzir", "fazer alegrar". $O$ yoco era uma planta que também operava por meio dessa causalidade social do aprendizado e facilitava o "viver bem" na comunidade como resultado do envolvimento de cada um. Quem vivia bem "fazia crescer" seus filhos, meninos e meninas, ensinando-lhes a pensar e agir por si mesmos através do exemplo, da palavra e do uso das plantas. Saber pensar, nesse sentido, acarretava saber fazer efetivamente aquilo que foi pensado. "Quem sabe fazer as coisas tem tudo o que precisa e pode dar para os outros”, me explicavam. Caso contrário, uma pessoa que não sabia fazer as coisas não tinha nada para dar, e essa era uma verdadeira fonte de conflitos. Por exemplo, a técnica da tecelagem era um dos conhecimentos principais transmitidos durante os rituais da puberdade masculina e uma fonte de produção efetiva durante o resto da vida dos homens. O primeiro presente que um jovem fazia para sua futura esposa era uma grande rede de tucum, onde o casal poderia deitar junto à noite e balançar as crianças durante o dia.

Hoje, trinta anos depois, a religião evangélica pentecostal se consolidou entre os Airo-Pai do Peru, e os rituais da puberdade masculina são coisas dos avôs. A maioria dos jovens escolarizados não bebe yaje, não realiza os resguardos necessários para o aprendizado e não tece finas redes de tucum. Alguns tomam yoco, mas poucos o fazem regularmente. Ainda assim, as histórias do tempo quando tomavam yaje continuam sendo contadas, e os ensinos do ritual da puberdade masculina ainda são referências de masculinidade. Os lugares onde eram erguidas, no passado, as "casas do yaje” (yaje hue’e) são conhecidos pelos rapazes escolarizados, pois os caminhos de caçada passam por perto. Ali, os meninos das antigas gerações ficavam semanas de resguardo juntos, aprendendo a tomar yaje, a ver os seres celestiais, a cantar com eles e a tecer as redes de tucum e todos os artefatos do tecido masculino. Essas casas eram construídas do lado de nascentes de água para cozinhar as bebidas de plantas. Como o som dos olhos de água, o eco dos cantos dos seres celestiais permanece lá. Este ano, em 2019, acompanhei Oscar, junto de sua esposa, da esposa de Liberato e de alguns de seus filhos e netos, em uma viagem para fazer o reconhecimento do seu território e identificar com GPS as coordenadas das "casas de yaje" no mapa. Oscar até falou em voltar a tomar yaje, de tanta força que ele sentia nos lugares, e destacou que ele, Cesário e Liberato nunca esqueceram 
os ensinos que receberam dos seres celestiais. "Como, aliás, ouviremos seus conselhos se não os chamarmos mais?", perguntou, lamentando o fato de que seus netos não contavam mais com essa guia. A sua esposa rapidamente respondeu que, agora, eles tinham os cantos do culto evangélico. Liberato faleceu no ano passado, em 2018. Ele permaneceu fiel à sua decisão de não tomar mais yaje, mas continuou tomando yoco e tecendo redes, peneiras e cestos para sua esposa, filhos, netos e bisnetos, até o final da vida.

\section{A DOBRA CÓSMICA E A “GENTE VERDE”}

O cosmos do xamanismo airo-pai é uma dobra com dois lados. A palavra tente, que Cesario, Oscar e Liberato traduzem como "lado", implica a ideia de um par de lados interconectados dinamicamente: iye tente, "este lado", e yeque tente, "o outro lado". A melhor maneira de apresentar essa interconexão entre os lados é citando as palavras de Don Cesario, que, com sua característica clareza, explicou o seguinte: "Quando temos os olhos abertos, vemos esse lado. Quando temos os olhos fechados, vemos o outro lado".

A chance de passar de um lado para o outro gera a possibilidade de mudar de ponto de vista. "Este lado" é o ponto de vista de quando estamos acordados, durante as atividades cotidianas, comuns a todos os homens, mulheres e crianças. É a maneira de ver e agir no ambiente familiar da comunidade, nas roças, nas florestas circundantes e na superfície dos rios. Ou seja, "este lado" é um lugar de perspectiva - um ponto de vista e também um campo de experiência perceptiva visionária e, mais amplamente, sensorial, afetiva e cognitiva. "O outro lado" está sempre potencialmente presente, mas, para acessar sua perspectiva, é preciso uma "visão" (toya) que faça passar para o "outro lado" por meio de uma "tontura" (huepeye), uma palavra que também significa "estar fraco", "se perder" ou "morrer". A tontura abre a visão do "outro lado" nos sonhos e nos estados visionários produzidos com a ingestão de plantas, como o yage (Banisteriopsis caapi), o toé (Brugmansia sp.) e o tabaco. A passagem para o "outro lado" também pode ocorrer com grandes movimentos do ar, tempestades e trovões, além de cheiros, odores repulsivos ou perfumados.

Os dois lados são sempre definidos relacionalmente, pois, para todo "este lado", existe um "outro lado". A dobra cósmica gera certa simetria entre os dois lados, mas também oferece elementos assimétricos. O "outro lado" não é apenas o inverso complementar "deste lado". Não há correspondência sistematicamente refletida entre os dois lados. O "outro lado" é sempre mais múltiplo, enquanto "este lado" é mais estável; ou melhor, o "outro lado" tem efeitos de multiplicidade, enquanto "este lado" tem efeitos de estabilidade. 
O "outro lado" é marcado pelo desconhecido e é potencialmente perigoso, enquanto "este lado" é mais familiar. Ver o "outro lado" é entender que toda percepção tem um "outro lado". Além disso, vendo "o outro lado", o sujeito da percepção entra nele e se torna vulnerável a seus efeitos. No "outro lado”, esse sujeito vê e é visto como geralmente não é visto nem vê. Ou seja, "o outro lado" se desdobra potencialmente em muitos "outros lados", todos eles potencialmente perigosos. Há também uma assimetria do conhecimento contido em ambos os lados. Apesar dos perigos, o conhecimento tem origem no "outro lado", e é trazido para "este lado". Essa é uma das tarefas do xamã curandeiro, que "faz seus parentes viverem" na comunidade graças à sua capacidade de atravessar a dobra cósmica $\mathrm{e}$ acessar o ponto de vista do "outro lado".

Frequentemente, no xamanismo airopai curandeiro e nos rituais de iniciação da puberdade, a expressão "outro lado" refere-se mais particularmente a um lugar (hueña) do cosmos que é uma esfera celestial (matëmo) onde reside a "gente verde" (wiña pai). Esses seres celestiais são chamados "verdes" no sentido de "sem amadurecer", como frutas verdes penduradas nas árvores. Para ter acesso ao lugar desses seres celestiais e, assim, para poder conversar com eles, o xamã precisa mudar sua "pele" (canihuë), o que também implica uma mudança de linguagem e percepção. A pele é o invólucro corporal do centro transcendente da pessoa, que é chamado de joyo, um conceito que os Airo-Pai traduzem em castelhano como o "coração". Este é o centro do pensamento, dos afetos e da memória pessoal. As técnicas xamânicas de resguardo, tomando plantas, guardando abstinência sexual e evitando o contato com o sangue menstrual, permitem liberar o coração do envoltório que o mantém "deste lado", para que possa atravessar a dobra cósmica em direção ao lugar da perspectiva dos seres celestiais do "outro lado" (Belaunde 2006).

O céu da "gente verde" está acima do "caminho do sol" (usë ma'a). Lá, eles vivem "acompanhando" (concaiye) a principal divindade xamânica Ñañe, "Lua", e sua esposa, Repao, também chamada pupuri jaco, a "Mãe dos Condores". Todos esses seres divinos ocupam o mesmo lugar celeste do cosmos, mas eles estão em casas diferentes (hue'e), como me explicavam. A "gente verde" caracterizase por ser eternamente jovem e nunca sofrer processos orgânicos de maturação e decomposição. Eles parecem meninos e meninas prestes a atingir a puberdade. Todos os meninos, por um lado, e todas as meninas, por outro, têm a mesma face, a mesma forma e o mesmo tamanho corporal. Eles carregam plantas perfumadas amarradas nos antebraços e colares de sementes penduradas no pescoço. Quando se movem, os colares soam "kiri 
kiri”, alegremente. Eles não têm preocupações nem precisam trabalhar duro, mas estão cheios de energia e alegria. Eles não andam, mas correm e dançam alegremente, e não falam, mas cantam. Eles vivem reunidos em malocas numerosas ao longo do rio divino, chamado "rio de praias de areia quente" (umeja siaya). Celebram grandes festas tomando cauim de macaxeira e chicha de milho, sem nunca brigar, e conseguem comida sem esforço, colhendo frutos das pequenas árvores que crescem nas margens do rio divino, de águas transparentes, retas e cheias de peixe (Cipolletti 1988a, 1988b, 2008; Moya 1992; Payaguaje 1990).

O lugar da "gente verde" não é um mundo incorpóreo. Pelo contrário, seus corpos são perfeitos e eternos; é um mundo em que a inércia, a dor e o trabalho doloroso não existem. Também não há brigas, doenças, nascimento e morte física, nem menstruação. Esses seres, juntamente com as divindades Lua e Mãe dos Condores, são considerados a expressão mais completa de "gente" (pai) no masculino e no feminino, respectivamente. Por esse motivo, seu lugar é considerado um pai hueña ("lugar da gente") por excelência. Seus corpos, ornamentos e alegria são uma fonte de inspiração para os vivos "deste lado", que tentam, na medida do possível, imitar seu exemplo, seguir seus ensinamentos e tornar as comunidades entre os vivos um "lugar da gente”, mesmo que parcial e sempre finito.
A questão da temporalidade e da finitude é fundamental para entender as relações entre os dois lados da dobra do cosmos airo-pai e a perspectiva da "gente verde". A dobra cósmica gera a diferença entre lugares da perspectiva e também uma diferença de temporalidades que caracterizam essas perspectivas. A "gente verde" nasce da ressurreição, no céu, dos mortos airo-pai. No entanto, nem todos os mortos conseguem alcançar esse estado de eterna juventude, e nem toda a "gente verde" é o produto da ressurreição dos mortos. Alguns deles sempre existiram e acompanharam Lua e Mãe dos Condores. Para ressuscitar no céu e "acompanhar" a "gente verde", os mortos devem ser preparados ritualmente pelos seus parentes na terra. Um xamã experiente deve contatar ritualmente a Mãe dos Condores e pedir que ela envie seus condores (urubus) para coletar o corpo do falecido. No céu, Mãe dos Condores lava a carne podre do cadáver, usando banhos perfumados de plantas nuni(Cyperus sp.) até deixar os ossos limpos. A partir desses ossos, a Mãe dos Condores gera com seus perfumes uma nova carne, cabelos e dentes, e a pessoa renasce como um menino ou uma menina de uns sete anos de idade. Depois de administrar mais perfumes, esses meninos passam a ter as características do corpo pré-púbico da "gente verde". Para completar sua ressurreição celestial, Mãe dos Condores lhes dá mais perfumes, primeiramente para esquecer 
os seus parentes na terra, e depois para obter o conhecimento divino de tudo o que existe. Por causa de seus perfumes de salvação, a Mãe dos Condores também é chamada nuni jaco, "mãe dos perfumes de nuni" (Payaguaje 1990; Cipolletti 1988b).

O objetivo explícito do xamanismo curandeiro e dos ensinos da puberdade airo-pai era estabelecer comunicação com a "gente verde", com Lua, com a Mãe dos Condores e outros seres celestiais, para obter conhecimentos, saúde, plantas medicinais e beleza. Essa comunicação era concebida como uma "conversa" (сосиа), na qual o xamã faz pedidos, aprende e vive experiências pessoais com as divindades. As palavras dos cantos xamânicos são, em grande parte, conversas durante as quais a "gente verde" fala e o xamã narra sua experiência no "outro lado". Considera-se que, se o xamã conseguir falar com esses seres celestiais, eles não rejeitarão seus pedidos. O difícil é se comunicar com eles, porque só os xamãs que passaram por resguardos estritos conseguem conversar com os seres divinos. Isso requer o cumprimento de longos períodos de dietas, isolamento, abstinência sexual, bem como necessita de coragem para suportar as dificuldades das experiências propiciadas pelas plantas.

Nos cantos xamânicos, além do denominativo "gente verde", os seres celestiais também aparecem com o de "gente vivente" (paico pai). Normalmente, esse é um autodenominativo utilizado pelos seres celestiais quando eles se referem a si mesmos. Como explicaram meus anfitriões, o qualificativo paico (vivente) indica que eles prodigam vida e ensinos para os mortais e, portanto, "fazem viver" os homens e as mulheres nesta terra. Já quando esses seres celestiais se referem aos vivos, eles os chamam de "crias", tanto de "filhotes" (si) como de "criados" (joya) de papagaios e de japus, respectivamente. Nos cantos do xamanismo da puberdade masculina, a ideia de criação e de ensino é manifestada por meio dos denominativos usados pelos seres celestiais para se referirem a si próprios e para se dirigirem aos meninos iniciados na ingestão de yaje.

\section{O CANTO DA "GENTE VIVENTE"}

O canto gravado por Oscar Vasquez Macanilla em 1989 foi aprendido por ele quando estava na "casa de yaje", durante a puberdade, tomando yaje e recebendo ensinamentos dos seres celestiais (Apêndice). Depois de cantar, Oscar traduziu livremente suas palavras em espanhol e me deu explicações espontâneas sobre o significado, linha por linha. Digo que ele fez uma tradução livre porque nossa metodologia de trabalho não cumpria a precisão de uma tradução linguística, e também porque, mais do que traduzir suas palavras, o que Oscar, Cesario e Liberato fizeram foi responder ao meu insistente e perseverante desejo de aprender. 
Eles me ensinavam em espanhol, interpretando para mim os ensinamentos que receberam durante a puberdade. Ao mesmo tempo, eles me mostravam o método airo-pai da exegese dos cantos. Havia, então, um duplo processo de tradução: do airo-pai para o espanhol, e da linguagem dos seres celestiais para a linguagem cotidiana. Por meio das suas explicações espontâneas, percebi que eles queriam que eu entendesse o canto para além das palavras, pois tudo o que os seres celestiais falam é um "conselho", que deve ser visualizado pelos meninos aprendizes. Escutar a fala dos seres celestiais, ver as visões que eles narram nos seus cantos e aprender por meio delas são aspectos inseparáveis.

Como demonstram etnografias mais recentes sobre o perspectivismo dos cantos xamânicos ameríndios (Lagrou 2018; Cesarino 2018), a exegese airo-pai de seus próprios cantos revela um conhecimento reflexivo sobre os processos de se tornar outro e os equívocos que surgem na passagem de uma perspectiva para a outra inerente a esses processos. Os homens airo-pai, com quem eu tive a sorte de aprender, também tinham um fascinante metaconhecimento sobre seus modos de conhecer, de ser, de falar, de ver e de ser visto nos dois "lados" da dobra cósmica. Com eles, eu aprendi que, nos cantos da puberdade masculina, há vários tipos de ensinamentos. Há os conselhos dos seres celestiais e também o ensinamento da exegese desses cantos e dos procedimentos linguísticos, que possibilitam uma dobradiça cósmica de tradução entre os "lados". Para poder mostrar essa relação entre as palavras do canto, o que essas palavras ensinam e como elas ensinam a traduzir essas palavras, utilizei uma tabela, disponível no Apêndice.

O canto descreve a cena da descida da "gente vivente" dos céus, à procura dos meninos airo-pai que estão sendo iniciados na "casa de yaje”, e narra como eles produzem diversos artefatos e constroem a casa comunal. As explicações de Oscar permitem compreender que a "gente vivente" ocupa a posição do sujeito da enunciação, narrando a cena e falando para os meninos. A "gente vivente" disse que eles descem alegres, enfeitados e perfumados, com os braços sobre os ombros uns dos outros, formando vários círculos de dançantes que baixam do céu consecutivamente. Carregam yoco amargo para beber e trazem diversas plantas. Estas plantas celestiais também são denominadas "viventes" (paico), sendo utilizadas como material para fazer diversos artefatos e construir a casa: tucum, para tecer as redes; fibra, para as peneiras, os cestos e os leques; cipós, para amarrar a estrutura de madeira; e folhas, para o teto da casa. Ao longo do canto, a "gente vivente" refere-se à sua disposição para trabalhar, cheia de pensamentos, alegria e propósitos de fazer juntos todos esses artefatos e a própria casa. 
As explicações de Oscar mostram que a cena pintada pelas palavras da "gente vivente" é ela própria uma visão, e a "gente vivente" exorta os meninos airo-pai a visualizarem a cena. Por exemplo, nas linhas 23 e 42 do Apêndice, as palavras iñanque yure, traduzidas como "veja agora”, são, ao mesmo tempo, um imperativo e uma pergunta. A "gente vivente" diz para os meninos que eles devem ver a cena narrada no canto, e também perguntam se eles estão vendo essa cena. A expressão iñanque yure é uma figura típica dos cantos xamânicos de ensinamento e cura, que age como um modo de gerar visões conjuntas entre todos os participantes na sessão xamânica. Além disso, as explicações de Oscar também permitem compreender que todas as atividades descritas no canto pela "gente vivente" são aconselhamentos. Os meninos airo-pai deveriam fazer aquilo que eles enxergam em visões quando escutam o canto da "gente vivente". Há, portanto, uma translação entre escuta, visão e ação, e esse movimento efetua o aprendizado, por meio dos ensinamentos do canto xamânico.

Em diversos momentos, a "gente vivente" se dirige aos meninos e os exorta explicitamente a terem, eles também, pensamentos "para frente", a tomarem yoco, a enfeitarem-se, produzirem os artefatos e a juntarem forças alegremente para construírem a casa. Nas linhas 15 e 28 do Apêndice, a "gente vivente" menciona o "ninho do japu" e as "crias do japu", dirigindo-se aos meninos como o término joyaë, dos aprendizes. As explicações de Oscar revelam que essa é a maneira como a "gente vivente" denomina a rede e os meninos: eles são aprendizes das técnicas de aninhar do japu. A rede é o ninho masculino, mas a sua tecelagem faz parte de um conjunto de outras tecelagens masculinas, inclusive da construção da própria casa e do tecido das folhas do teto.

A partir da linha 35 do Apêndice, o canto muda de foco para a "nossa mãe", isto é, para a casa construída. A própria "mãe" fala no canto e se autodenomina "mãe vivente" (paico jaco). Ela se enfeita e exorta os meninos a acordarem e a ficarem de pé. Essa postura corporal é a dos pensamentos dispostos para o trabalho, que caracteriza os seres celestiais "viventes", pois, ao longo do canto, eles chegam "de pé". Quando os meninos aprendem com os seres celestiais "viventes" a fazer seus ninhos, também aprendem a tecer todos os artefatos necessários do dia a dia e a fazer a própria casa onde seus ninhos estão pendurados.

No canto, há uma mistura de palavras com sentido cotidiano com outras que Oscar traduz para a linguagem cotidiana. Destaca-se a listagem de plantas que são nomeadas consecutivamente, começando pelo yoco, trazido do céu e cujo sabor amargo, de acordo com as explicações de Oscar, 
indica seu potente efeito de aconselhamento, "despreguiçando" e infundindo bons propósitos (linhas 4, 5 e 6 do Apêndice). Depois, são nomeadas as plantas para se enfeitar, huirisaca, yapé e uoton, e as folhas, mienpi e yaicahuano, para tecer o teto. O yoco é nomeado novamente, na linha 24 do Apêndice, quando o aconselhamento para tecer os ninhos e outros artefatos termina, sendo iniciado o aconselhamento para o esforço coletivo de construir a casa. Então, são nomeadas as madeiras, o cipó para amarrá-las e o urucum, que enfeita a nova casa. Esses nomes de plantas são literais, pois as mesmas palavras são usadas "neste lado" para nomeá-los cotidianamente; mas o qualificativo "vivente" indica que são plantas celestiais e infundem vida aos meninos. As únicas palavras do canto que Oscar traduz para a linguagem cotidiana são aquelas usadas para denominar a rede ("ninho de japu"), os meninos ("crias de japu”) e a casa ("nossa mãe").

Cabe anotar também que há uma relação de replicação entre a cena virtual descrita no canto e a situação dos meninos recluídos na "casa de yaje", pois, além de aprenderem a beber yaje, os meninos airo-pai passavam o resto do tempo aprendendo a tecer. A "casa de yaje", que era construída na floresta para albergar os meninos durante o ritual da puberdade, e a casa "nossa mãe", construída no canto pelos seres celestiais e as crias de japus, são duplos. A produção da masculinidade colocada no palco pelo canto da puberdade masculina envolve um complexo nexo de relações entre plantas e japus, que compõem a casa.

\section{EMARANHADOS DE RELAÇÕES INTERESPÉCIES}

Deve-se notar que, no dia a dia, os japus da floresta "deste lado" são considerados "seres da floresta" (airoco), e podem ser caçados para se obter penas, a fim de se fazer ornamentos corporais; ocasionalmente, quando se encontram filhotes, eles são levados para casa, mas isso acontece raramente. O mesmo acontece com os papagaios, que são xerimbabos queridos, mas não são muito comuns. As aves preferidas para serem criadas em casa são os pares de periquitos mais pequenos. Portanto, a relação na vida diária entre os Airo-Pai, os japus e os papagaios do ambiente florestal não se destaca como uma relação de predação familiarizante, focada na incorporação do não humano ao nexo de parentesco humano (Fausto 2008; Brightman et al. 2016), nem como uma relação de criação baseada na assimetria entre o humano, que dá comida, e o não humano, que é alimentado (Costa 2017). No entanto, bandos de japus e papagaios voam livremente e fazem parte do ritmo diário das comunidades airo-pai. Frequentemente, as casas são construídas perto de árvores onde os japus 
se aninham e podem ser ouvidos no crepúsculo, animando o local. Os casais de papagaios também cruzam o céu à tarde, animando a todos. Ou seja, esses pássaros da floresta fazem parte da paisagem e do cotidiano das comunidades airo-pai.

Se retomarmos a leitura totêmica dos filhotes de aves airo-pai sugerida por Viveiros de Castro (Viveiros de Castro \& Belaunde 2007), e se focarmos nas diferenças entre as espécies de pássaros, por um lado, e nas diferenças entre os gêneros humanos, por outro, estaremos diante de uma fórmula canônica lévi-straussiana do tipo $\mathrm{A} / \mathrm{B}=\mathrm{C} / \mathrm{D}$.

As diferenças entre os papagaios e os japus são semelhantes (ou homólogas) às diferenças entre as mulheres e os homens

Mais precisamente, estaríamos frente a um totemismo de gênero, onde as formas de aninhar são o elemento-chave da equação:

\section{As diferenças entre formas de reprodução das mulheres e dos homens são semelhantes (ou homólogas) às diferenças entre as formas de nidificar dos papagaios e dos japus}

De fato, as diferenças entre as espécies de pássaros eram salientadas pelos meus anfitriões. Pude ver que, a partir do contraste entre as formas de nidificação, eles indicavam outras diferenças entre seus hábitos e habitats. Além de fazer ninhos em buracos nos troncos das árvores, o papagaio era famoso por sua cor verde e por ser muito falante, por se alimentar principalmente de sementes, moendo-as com o gancho de seu bico, e por comer argila das falésias. O japu, além de tecer ninhos e pendurá-los nos galhos, era famoso por ter a cor preta e sua cauda apresentar plumagem amarela, por ser um excelente cantador e por se alimentar de insetos e frutas que ele pegava com seu afiado bico. Não apenas seus ninhos eram contrastados, mas também seus alimentos, seus instrumentos, seus métodos de defesa e de combate e até as formas de relacionamento entre as fêmeas e os machos de cada espécie, pois os casais de papagaios fazem tudo juntos, enquanto os casais de japus fazem coisas diferentes.

Ambas as aves são muito gregárias, talvez essa seja a única característica marcante que compartilham e que era enfatizada pelos Airo-Pai. Eles raramente são vistos sozinhos, sempre andam em casal ou em bandos, compartilhados com outras espécies companheiras. Os papagaios voam na companhia de tucanos e de periquitos, e os japus tecem seus ninhos em árvores onde também se aninham as temidas vespas e formigas, que atacam os pássaros invasores que se aproximam para roubar os ninhos de japu. Ou seja, mesmo na maneira de se associar com outros seres no ambiente, os papagaios e os japu diferem. No dia a dia, essas diferenças entre as aves eram utilizadas como diacríticos das diferenças entre as mulheres e os homens. Por exemplo, com típico sentido do humor, observavam que as mulheres chateadas falavam alto que nem os papagaios 
enfurecidos, enquanto os homens brigavam com armas afiadas que nem os japus.

No entanto, se permanecermos focados nas diferenças entre as espécies de aves como diacríticas das diferenças entre os gêneros (humanos), invisibilizaremos o pensamento dos Airo-Pai que estabelece analogias diretas entre cada gênero e seu respectivo pássaro, e que sustenta seu perspectivismo associado à dobra cósmica. Como Oscar, Cesario e Liberato explicaram consistentemente, a percepção dos seres celestiais do "outro lado" repousa nas semelhanças entre os comportamentos dos gêneros e de seus pássaros. Essas semelhanças são percebidas "neste lado" na vida cotidiana e expressam-se por meio da noção de "parecer" (je paiye).

Essa noção do pensamento ameríndio foi destacada desde o início dos estudos da perspectiva ameríndia (Århem 1993; Viveiros de Castro 1996; Lima 1996). Por exemplo, entre os Makuna, a noção de "parecer" é uma dobradiça que permite transitar entre perspectivas. Esse trânsito pela dobra entre "este" e o "outro lado" também é conduzido pelos Airo-Pai. As suas exegeses dos relatos e cantos mostram a grande habilidade que possuem para dar conta da mudança de percepção de um "lado" para o outro. Nesse "lado", um homem "parece japu" (umuje paiye) porque tece ninhos semelhantes aos japus, mas, no "outro lado", os seres celestiais o veem e o chamam de "filhote de japu" (umusi) e um "criado do japu" (umu joyaë). Da mesma forma, "deste lado" uma mulher "parece papagaio" (hue'ecoje paiye) porque aninha em um tronco, mas, no "outro lado", os seres celestiais a veem e a chamam de "filhote de papagaio" (hue'ecosi) ou "criada pelo papagaio" (hueco joyao).

Fica claro, porém, que as complexas relações de similaridade observadas "deste lado" entre os gêneros e seus respectivos pássaros (incluindo as conexões interespecíficas que os cercam) inevitavelmente também apontam as diferenças entre os gêneros e entre as espécies. Há um deslize fácil das semelhanças entre um gênero e seu pássaro em relação às diferenças entre os gêneros (que se assemelham às diferenças entre os pássaros). Esse deslize também é um deslizamento entre perspectivas. É um jogo constante de relações entre relações. Nesse "lado", as semelhanças ocupam o primeiro plano, e as relações entre os gêneros e seus respectivos pássaros são "aparentes”. No "outro lado", para os seres celestiais, as diferenças entre os gêneros tomam o primeiro plano, e os gêneros são vistos e chamados de crias de duas espécies diferentes de aves, que se reproduzem separadamente. Ou seja, a perspectiva do "outro lado" literaliza (Viveiros de Castro 2008:111) as semelhanças entre os gêneros e seus pássaros respectivos e, portanto, radicaliza a diferença de gênero.

Somos, então, confrontados com um pensamento totêmico, que concebe as semelhanças entre duas séries de diferenças (as 
diferenças entre os gêneros e entre as espécies de aves), e um pensamento perspectivista, que nos permite passar da perspectiva do "outro lado" para a "deste lado", por meio das dobradiças que estabelecem relações de similitude entre uma espécie de ave e um gênero. É possível mover-se de um lado para o outro. As relações de "parecer" "desse lado" são articuladas às relações de diferença de perspectiva do "outro lado". Não pretendo me aprofundar nas considerações teóricas sobre as relações de transformação estrutural entre totemismo e perspectivismo colocadas por Viveiros de Castro (2008) e examinadas em detalhe por Kelly (2010). No nosso caso, como sugeriu a leitura do próprio Viveiros de Castro, o perspectivismo dos filhotes de pássaro pode ser lido a partir da fórmula canônica e, nesse sentido, pode ser considerado uma transformação de um totemismo de gênero.

Um ponto interessante é que o homem airopai não está apenas associado ao japu-macho, mas também à fêmea (ou seja, ao par dessa espécie). De certa forma, pode-se dizer que ele mantém uma relação andrógina com esta espécie, na medida em que o homem airo-pai realiza as atividades características dos japus de ambos os sexos. De fato, os japus exibem uma divisão clara do trabalho de produção e de cuidado do ninho, pois a fêmea tece, enquanto o macho mantém certa distância, guardando e avisando, com seu canto, quando um perigo se aproxima. Os homens airo-pai tecem como as fêmeas e cantam como os machos japu. Assim, eles se assemelham aos dois sexos da espécie de ave. O mesmo vale para o relacionamento entre a mulher airo-pai e o papagaio. A mulher realiza as atividades do macho e da fêmea dessa espécie de ave, cujos parceiros são reconhecidos por permanecerem juntos a maior parte do tempo. Além disso, casais de papagaios são exemplos de comunhão, e sua união dura ao longo da vida. Os casais japus, pelo contrário, podem brigar entre si, o macho pode ter várias fêmeas e seus ninhos podem ser usurpados por machos de outras espécies. Cada espécie de pássaro, ou seja, cada gênero humano, tem seu próprio estilo de relações de gênero. Portanto, existe uma androginia, na medida em que cada gênero humano e sua maneira de aninhar mantêm semelhança com ambos os sexos do par de pássaros.

Não entrarei em mais detalhes sobre as outras semelhanças assinaladas pelos Airo-Pai entre os gêneros e seus pássaros respectivos. Mas fica claro que essas analogias entre humanos e não humanos são indissociáveis das diferenças percebidas entre os gêneros humanos, por um lado, e entre as 
espécies de aves, por outro. Também é importante destacar que, por trás de cada espécie de ave, existe uma rede de conexões com outras aves, insetos, árvores e plantas que, portanto, também mantêm relações com os gêneros humanos. Além disso, mulheres e homens são associados ao mesmo tempo a um filhote de passarinho, ao ninho onde é criado e à árvore onde o ninho é encontrado com os filhotes.

Por exemplo, o canto da puberdade masculina apresentado no Apêndice mostra que o ensino xamânico da masculinidade envolve relações entre japus e uma diversidade de plantas. Para aprenderem a tecer seus ninhos de japu e todos os artefatos necessários em casa, os meninos recebem plantas da "gente vivente": yoco, para "despreguiçarem-se", enfeites, perfumes e materiais de tecido e construção. Todas essas plantas fazem parte desse nidificar masculino, que culmina na construção da própria casaárvore, com seus colares de folhas. Portanto, existe um fractal entre árvore, casa, ninho, corpo e órgãos reprodutivos de cada gênero ${ }^{2}$. Nesse sentido, a etnografia airo-pai ressoa com a análise da pessoa fractal, apontada por Lima (2005), no seu estudo sobre a criação, o gênero e a perspectiva do cauim entre os Yudjá.
Destaco o yoco, pois essa planta é tão importante quanto o yaje para a constituição da masculinidade. Atualmente, com a adesão ao evangelismo e o abandono do yaje, seu uso, mesmo irregular, mantem a conexão com as práticas cotidianas e rituais do passado. $\mathrm{Na}$ "casa de yaje", os meninos acessavam aos aconselhamentos do yoco celestial enquanto crias de japus. Portanto, as relações entre o japu e os homens passavam pelas suas relações com o yoco. Mas, para os Airo-Pai, o yoco não era só um cipó que existia na floresta e no céu; ele era também um tipo de gente celestial, chamada "gente yoco" (yoco pai). Além disso, em sonhos, essa planta era vista como um mutum (Cracinae); e, do ponto de vista da sua ave dispersora, o capitão do mato (Lipaugus vociferans), os brotos de yoco na floresta eram a sua horta. Não há espaço neste artigo para detalhar as múltiplas perspectivas sobre yoco que analisei em outros textos (Belaunde \& Echeverri 2008a, 2008b), mas acho importante sublinhar que o yaje e o yoco fazem parte do emaranhado de relações entre espécies de plantas e animais, tecido em torno das relações de gênero airo-pai.

Embora a fórmula canônica lévi-

2 Em Belaunde (1994), há análise de um canto xamânico de cura feminina e estudo do útero, concebido como uma casa mobiliada, com uma rede onde o feto balança. 
straussiana seja, até certo ponto, adequada à etnografia airo-pai dos filhotes de pássaros, as relações interespecíficas que sustentam seu perspectivismo de gênero transbordam essa equação. O pensamento airo-pai estabelece semelhanças e diferenças entre os gêneros humanos e essas aves, com base no conhecimento detalhado de seus hábitos e habitats e das espécies de animais e vegetais que fazem parte de seus comportamentos e seus nichos ecológicos. Esse reconhecimento de semelhanças e diferenças se estende como uma malha de conexões para além das fronteiras entre animais e plantas: como um emaranhado de elementos compartilhados horizontalmente, que cruzam as diferenças entre as espécies e entre humanos e não humanos. Nesse sentido, a etnografia airo-pai também ressoa com as propostas de Ingold (2011) e Kohn (2013), e podemos entender como o pensamento da selva se estende a todos os assuntos da floresta, ofuscando as fronteiras interespécies.

\section{CONCLUSÕES: A PERSPECTIVA DA ETERNA JUVENTUDE}

O pensamento dos Airo-Pai não apenas mobiliza semelhanças e diferenças interespecíficas, mas também traz relações entre temporalidades. A diferença entre os vivos, que vão morrer, e os seres eternos, surgidos dos mortos ressuscitados no céu, articula e sustenta a homologia entre as duas séries de diferenças anteriores (os pássaros e os gêneros humanos). A etnografia airopai sobre os filhotes de aves levanta mais do que uma questão de gênero, pois inclui também uma questão de criação e, portanto, de crescimento e temporalidade. O que significa ser visto como um filhote pelos seres celestiais, e como a temporalidade é uma chave fundamental para a diferença de perspectiva?

É nesse ponto que a diferença de temporalidade entre os seres celestiais e os vivos é, na minha opinião, um aspecto central do perspectivismo de gênero airo-pai, que o separa de um totemismo de gênero e o aproxima às propostas de Lima (1996) e Overing (1990), já que para ambas o tempo é fundamental nas cosmologias ameríndias. Os seres celestiais, associados aos mortos ressuscitados no céu em uma pré-puberdade permanente, veem os vivos como crias. Isto é, eles os veem como seres ternos, que precisam de cuidados e ensinamentos. O olhar dos seres celestiais airo-pai não opera uma predação ontológica. Nos cantos da puberdade masculina e nos cantos de cura, os humanos não são vistos como presas pelos seres celestiais (Belaunde 1994). Não há uma predação, mas uma criação de filhotes, na qual tanto o sujeito quanto o objeto da percepção são caracterizados por serem jovens, cada um à sua maneira, pois há uma grande diferença no modo como os seres celestiais e os 
vivos são jovens. Os seres celestiais são "verdes", ficando eternamente sem amadurecer. Nesse sentido, eles não crescem, não estão submetidos aos fluxos orgânicos. Homens e mulheres vivos, por outro lado, estão crescendo, estão amadurecendo e vão envelhecer e se decompor. Sua juventude e alegria é efêmera; é apenas um momento em suas vidas. Como dizem os Airo-Pai, carajai, eles se "acabam".

O olhar dos seres celestiais sobre os vivos confere renovação ou "salva" (huajeye). Dessa forma, o xamanismo curandeiro e o dos ensinos da puberdade airo-pai visavam se comunicar com os seres celestiais, ser vistos por eles como filhotes, para receberem suas plantas celestiais e seus aconselhamentos. E, como vimos no canto da puberdade masculina, o filhote não está solto ou sozinho. Está no ninho, acompanhado pelos outros filhotes, com os quais está sendo criado. O ensino dos seres celestiais consiste em ensinar a fazer ninhos, pessoais e comunais.

A predação não está ausente no xamanismo airo-pai (Belaunde 2000b). Ela opera, por exemplo, no xamanismo da caçada e da feitiçaria, a partir do embate entre os pontos de vista da presa e do predador, como Lima (1996) argumentou para os Yudjá. Mas, no xamanismo da puberdade e da cura, não existe predação nem embate entre a perspectiva dos seres celestiais e a dos vivos. Ser capturado pela perspectiva dos seres celestiais é ser "salvo". Os vivos desejam e procuram ser olhados pelos seres celestiais, ver o que eles veem e apreender por meio dessas visões e aconselhamentos. Se o xamã segue os resguardos de comida, de abstinência sexual e evita o contato com o sangue menstrual, não há inimizade com os seres celestiais. Quando esses resguardos não são respeitados, ao invés de terem inimizade, o que acontece é que os seres celestiais não respondem, fogem ou se escondem dos vivos que tentam entrar em contato com eles. Eles não permitem que os vivos acessem sua perspectiva.

Resta perguntar: quem são os adultos desses filhotes de pássaros? Minha resposta é que a questão da idade adulta de pássaros e seres celestiais não é algo elaborado pelo xamanismo da cura e dos aconselhamentos. O que quero dizer é que a cria - sendo tenra, pequena, vulnerável, crescendo no ninho - é a razão de ser do xamanismo de cura e dos ensinos da puberdade. Estar na posição do filhote é ontologicamente eficaz para os vivos. Retemporaliza a existência "deste lado", impregnando-a com um sopro de juventude eterna, que permite "alegrar-se", isto é, viver como filhotes. Em um cosmos onde a juventude eterna caracteriza os seres celestiais, tanto os que são criados quanto os que os criam são jovens.

No que diz respeito às relações entre corpo, alma e tempo levantadas pelas propostas perspectivistas de Lima (1996, 2002, 2005), a etnografia airo-pai acrescenta uma nuance da temporalidade. A ideia de que os "filhotes de japu" e os "filhotes de papagaio" 
são o "coração" de mulheres e homens é um tema que alguns airo-pai me mencionaram, embora nem todos pareçam concordar ou saber sobre isso. É um tema mais esotérico de seu xamanismo, ao qual não tive muito acesso. No entanto, a ideia de que o coração é visto como uma cria, um ser jovem, é um aspecto importante a ser explorado. Poder-se-ia acreditar que, nos cantos da puberdade, os meninos são vistos como crias porque eles, efetivamente, eram jovens. Mas, nos cantos xamânicos da cura, que se aplicavam às pessoas doentes de todas as idades, inclusive adultos e velhos, os vivos também eram chamados de filhotes de pássaros pelos seres celestiais, independentemente da idade. Apesar do passar dos anos, seus corações continuam jovens para os seres celestiais. O contraste entre as duas temporalidades, a eterna juventude do "outro lado" e a temporalidade do envelhecimento “deste lado", é, portanto, mediado pela juventude do coração. Dentro de sua finitude temporal, os vivos têm um coração que, para seres eternamente jovens, também é sempre jovem. Na minha opinião, esse jogo de temporalidades contrastadas nos permite entender melhor como os Airo-Pai buscavam efetivamente a alegria no dia a dia, tentando emular a saúde e a beleza dos seres celestiais. Tornar-se filhotes de duas espécies de aves em seus ninhos, alegrando-se, é o tempo presente dos mortais.

\section{REFERÊNCIAS}

Århem, K. 1993: Ecosofía makuna, in La selva humanizada: ecología alternativa en el trópico húmedo colombiano. Organizado por F. Correa, pp. 109-126. Bogotá: Instituto Colombiano de AntropologíaFondo FEN Colombia/Fondo Editorial CEREC.

Belaunde, L. E. 1994. Parrots and oropendolas: the aesthetics of gender relations among the Airo-Pai of the Peruvian Amazon. fournal de la Société des Américanistes (80):95-111.

Belaunde, L. E. 2000a. The convivial self and the fear of anger amongst the Airo-Pai of Amazonian Peru, in The Anthropology of love and anger. Organizado por J. Overing, e A. Passes, pp. 209-220. London: Routledge. v. 1. DOI: http://dx.doi.org/10.4324/9780203184653-11.

Belaunde, L. E. 2000b. Epidemics, Psycho-Actives and Evangelical Conversion among the Airo-Pai of Amazonian Peru. fournal of Contemporary Religion 15(3):349-359. DOI: https://doi.org/10.1080/713676037. 
Belaunde, L. E. 2001. Viviendo bien: género y fertilidad entre los Airo-Pai de la Amazonia Peruana. Lima: CAAAP.

Belaunde, L. E. 2006. A força dos pensamentos, o fedor do sangue. Hematologia e gênero na Amazônia. Revista de Antropologia 49(1):205-243. DOI: http://dx.doi.org/10.1590/S0034-77012006000100007.

Belaunde, L. E., e J. A. Echeverri. 2008a. Como un padre que da consejo: Paullinia yoco entre los airopai del Perú, in: Pueblos indígenas, plantas y mercado. Organizado por M. Lenaerts, e M. Spadafora, pp. 107-135. Bucareste: Zeta Books.

Belaunde, L. E., e J. A. Echeverri. 2008b. El yoco del cielo es cultivado: perspectivas sobre Paullinia yoco en el chamanismo airo-pai (Secoya-Tucano Occidental). Antropologica (26):75-92.

Brightman, M., C. Fausto, e V. Grotti (ed.). 2016. Ownership and nurture. Studies in native Amazonian property relations. New York/Oxford: Berghahn.

Brown, M. 1985. Tsewa's gift. Magic and meaning in an Amazonian society. Washington: Smithsonian Institution Press.

Cesarino, P. 2018. Virtualidade e equivocidade do ser nos xamanismos ameríndios. Revista do Instituto de Estudos Brasileiros (69):267-288. DOI: https://doi.org/10.11606/issn.2316-901X.v0i69p267-288.

Cipolletti, M. S. 1988a. El animalito doméstico quedó hecho cenizas: Aspectos del lenguaje shamánico secoya, in Lenguaje y palabras chamánicas. Coordenado por P. Bidou, e M. Perrin, pp. 9-34. Quito: Abya-Yala.

Cipolletti, M. S. 1988b. El piri piri (ciperáceas) y su significado en el shamanismo secoya. Amazonía Peruana 8(15):83-97.

Cipolletti, M. S. 2008. La fascinación del mal. Historia de vida de un shaman secoya de la Amazonía ecuatoriana. Quito: Abya Yala. 
Costa, L. 2017. The owners of kinship. Assymmetrical relations in Indigenous Amazonia. Chicago: The University of Chicago Press.

Crocker, C. 1977. My brother the parrot, in The social use of metaphore. Organizado por J. Sapir, e C. Crocker, pp. 164-192. Philadelphia: University of Pensylvania Press.

De la Cadena, M. 2015. Earth beings: ecologies of practices across Andean world. Durham: Duke University Press.

Descola, P. 1986. La nature domestique. Symbolisme et práxis dans l'écologie des Achuar. Paris: Éditions de la Maison des Sciences de l'Homme.

Descola, P. 2001. The genres of gender: local models of global paradigms in the comparison of Amazonia and Melanesia, in Gender in Amazonia and Melanesia: an exploration of comparative metod. Editado por T. Gregor e D. Tuzin, pp. 91-114. Berckeley: University of California Press.

Fausto, C. 2008 Donos demais: maestria e domínio na Amazônia. Mana 14(2):329-366. DOI: http:// dx.doi.org/10.1590/S0104-93132008000200003.

Haraway, D. 2003 The companion species manifesto: dogs, people, and significant otherness. Chicago: The University of Chicago Press/Prickly Paradigm Press.

Ingold, T. 2011. Being alive: essays on movement, knowledge and description. London: Routledge.

Kohn, E. 2013. How forests think: toward an Anthropology beyond the Human. Berkeley: The University of California Press.

Kelly, J. 2010. Perspectivismo multicultural como transformação estrutural. Ilha 12(1):135-160.

Lagrou, E. 2018. Anaconda becoming: Huni Kuin image songs, an ameríndia relational aesthetic. 
Horizontes Antropológicos 24(51):17-49. DOI: http://dx.doi.org/10.1590/s0104-71832018000200002.

Langdon, J. 1979. Yage among the Siona: cultural patterns in visions, in Spirits, shamans and stars.

Editado por D. Borwman, e R. Schwarz, pp. 63-80. The Hague: Mouton Publishers.

Langdon, J. 2014. La negociación de lo oculto. Popayán: Universidad del Cauca.

Lévi-Strauss, C. 1962. Le totémisme aujourd'hui. Paris: Plon

Lima, T. 1996. O dois e seu múltiplo: reflexões sobre o perspectivismo em uma cosmmologia tupi. Mana 2(2):21-47. DOI: http://dx.doi.org/10.1590/S0104-93131996000200002.

Lima, T. 2002. O que é um corpo? Religião e Sociedade 22(1):9-20.

Lima, T. 2005. Um peixe olhou para mim. O povo Yudjá e a perspectiva. São Paulo: UNESP.

Moya, R. 1992. Requiem por los espejos y los tigres. Quito: Abya-Yala.

Overing, J. 1990. The shaman as a maker of worlds. Nelson Goodman in the Amazon. Man, News Series 25(4):602-619. DOI: http://dx.doi.org/10.2307/2803656.

Payaguaje, F. 1990. El bebedor de yajé: Fernando Payaguaje. Aguarico: CICAME.

Taussig, M. 1993. Mimesis and alterity: a particular history of the senses. New York: Routledge.

Townsley, G. 1993. Song paths. The ways and means of Yaminahua shamanic knowledge. L'Homme 33(126-128):449-468.

Vickers, W. 1989. Los siona y los secoya. Su adaptación al medio ambiente. Quito: Abya-Yala. 
Viveiros de Castro, E. 1996. Os pronomes cosmológicos e o perspectivismo ameríndio. Mana 2(2):115144. DOI: http://dx.doi.org/10.1590/S0104-93131996000200005.

Viveiros de Castro, E. 2008 Xamanismo transversal: Lévi-Strauss e a cosmopolítica amazônica, in LéviStrauss: leituras brasileiras. Editado por R. Caixeta, e E. Nobre, pp. 79-124. Belo Horizonte: Ed. UFMG.

Viveiros de Castro, E., e L. E. Belaunde. 2007. O perspectivismo é a retomada da antropofagia oswaldiana em novos termos, in Eduardo Viveiros de Castro: entrevistas. Organizado por R. Sztutman, pp. 115-130. Rio de Janeiro: Azougue. 
APÊNDICE - Canto gravado por Oscar Vasquez Macanilla em 1989.

As explicações espontâneas do cantor foram inseridas entre parênteses.

\begin{tabular}{|c|c|c|}
\hline & Palavras do canto & Tradução livre e explicações espontâneas do cantor \\
\hline 1 & $\begin{array}{l}\text { Yequë maña daipë } \\
\text { nёca menquë }\end{array}$ & $\begin{array}{l}\text { Chegamos de pé descendo } \\
\text { (É a "gente vivente" paico pai que está falando. Eles dizem que estão } \\
\text { chegando de pé, descendo do lugar celestial onde eles moram para } \\
\text { encontrar os meninos airo-pai) }\end{array}$ \\
\hline 2 & $\begin{array}{l}\text { Ponë ponë kiri kiri } \\
\text { paico paipi }\end{array}$ & $\begin{array}{l}\text { (A "gente vivente" vem descendo dançando e seus colares fazem o } \\
\text { som ponë ponë kiri kiri) }\end{array}$ \\
\hline 3 & Cuine yeque totamo & $\begin{array}{l}\text { Também outro círculo } \\
\text { (A "gente vivente" vem descendo formando vários círculos de dan- } \\
\text { çantes, com os braços sobre os ombros um do outro) }\end{array}$ \\
\hline 4 & $\begin{array}{l}\text { Cauipë nëca menquë } \\
\text { yocoti maña cauipë } \\
\text { nëca menquë }\end{array}$ & $\begin{array}{l}\text { Carregando os cipós de yoco de pé descendo } \\
\text { (A "gente vivente" aconselha os meninos airo-pai para que eles vi- } \\
\text { vam bem como o yoco, porque com o yoco a gente vive tranquilo. } \\
\text { Yoco é como um pai, ele faz as pessoas fazerem todo tipo de traba- } \\
\text { lhos) }\end{array}$ \\
\hline 5 & $\begin{array}{l}\text { Yocoti maña cuaipë } \\
\text { doi menquë }\end{array}$ & $\begin{array}{l}\text { Carregando yoco para uma visita descendo } \\
\text { (Eles dizem que estão chegando para visitar os meninos airo-pai, } \\
\text { mas isso é um conselho de que bebendo yoco a gente vive bem) }\end{array}$ \\
\hline 6 & Sëjene & $\begin{array}{l}\text { Amargo } \\
\text { (É o sabor amargo do yoco que os meninos airo-pai bebem com a } \\
\text { "gente vivente") }\end{array}$ \\
\hline 7 & $\begin{array}{l}\text { Paico huirisacapi } \\
\text { nёca menquë }\end{array}$ & $\begin{array}{l}\text { Huirisaca folhas viventes de pé descendo } \\
\text { (A "gente vivente" traz huirisaca, folhas perfumadas colocadas como } \\
\text { enfeites nos antebraços) }\end{array}$ \\
\hline 8 & $\begin{array}{l}\text { Paico yapepi пёса } \\
\text { menquë quërërë }\end{array}$ & $\begin{array}{l}\text { Yape folhas viventes de pé descendo } \\
\text { (A "gente vivente" traz yape, folhas perfumadas colocadas como } \\
\text { enfeites nos antebraços) }\end{array}$ \\
\hline 9 & $\begin{array}{l}\text { Cuatsaye paani je- } \\
\text { teyoje }\end{array}$ & Não pense para trás \\
\hline 10 & Cuatsaye duduna & Pense para frente \\
\hline 11 & $\begin{array}{l}\text { Uoton manca paime } \\
\text { nëca menquë }\end{array}$ & $\begin{array}{l}\text { Perfumados de pé descendo } \\
\text { (A "gente vivente" vem alegre, dizendo que, quando a gente usa } \\
\text { folhas perfumadas, a gente trabalha com entusiasmo) }\end{array}$ \\
\hline 12 & Yequë maña daipë & Chegamos na aldeia \\
\hline 13 & $\begin{array}{l}\text { Penca penca kiri kiri } \\
\text { nëca menquë paico } \\
\text { pai }\end{array}$ & $\begin{array}{l}\text { (A "gente vivente" de pé descendo fazem o som penca penca kiri } \\
\text { kiri) }\end{array}$ \\
\hline
\end{tabular}




\begin{tabular}{|c|c|c|}
\hline 14 & $\begin{array}{l}\text { Cuine yeque totamo } \\
\text { nëca menqué iñäe } \\
\text { nëcato }\end{array}$ & $\begin{array}{l}\text { Veja mais um círculo de dançantes descendo } \\
\text { (A “ gente vivente” chama a atenção dos meninos airo-pai para que } \\
\text { eles vejam mais dançantes chegando) }\end{array}$ \\
\hline 15 & Umuturu maña jodë & $\begin{array}{l}\text { Tecendo o ninho do japu } \\
\text { (A "gente vivente" aconselha os meninos mostrando como se tecem } \\
\text { as redes, que chamam de ninhos de japu) }\end{array}$ \\
\hline 16 & Сиаё manca & $\begin{array}{l}\text { Cheios de pensamentos com propósitos } \\
\text { (Com os pensamentos cheios de propósitos da "gente vivente". A } \\
\text { gente vive bem, vive tranquilo) }\end{array}$ \\
\hline 17 & $\begin{array}{l}\text { Cuine yeque totamo } \\
\text { iñajë nëcato }\end{array}$ & Veja mais um círculo de dançantes descendo \\
\hline 18 & Cuä̈ manca & Cheios de pensamentos com bons propósitos \\
\hline 19 & Paico mienpi jode soë & $\begin{array}{l}\text { Tecendo as folhas mienpi viventes do teto } \\
\text { (A "gente vivente" tece as folhas de palmeira do teto da casa) }\end{array}$ \\
\hline 20 & Sie tro sie tro & $\begin{array}{l}\text { (Quando a gente vivente tece as folhas do teto, fazem o som sie tro } \\
\text { sie tro) }\end{array}$ \\
\hline 21 & $\begin{array}{l}\text { Yaicahuano sehuë } \\
\text { menquë }\end{array}$ & $\begin{array}{l}\text { Trazemos o cipó yaicahuano } \\
\text { (A "gente vivente" traz o cipó yaicahuano (Cyclanthaceae sp.), usado } \\
\text { para amarrar a estrutura de madeira da casa) }\end{array}$ \\
\hline 22 & $\begin{array}{l}\text { Yaicahuano maña } \\
\text { huë éjë dayë }\end{array}$ & $\begin{array}{l}\text { Trazemos carregando o cipó yaicahuano para fazer a casa } \\
\text { (Esse é um conselho da "gente vivente", mostrando para os meninos } \\
\text { airo-pai como se constrói a casa) }\end{array}$ \\
\hline 23 & Iñanque yure & $\begin{array}{l}\text { Veja agora } \\
\text { (A "gente vivente" pergunta para os meninos airo-pai se eles estão } \\
\text { vendo tudo aquilo que está sendo falado no canto) }\end{array}$ \\
\hline 24 & $\begin{array}{l}\text { Yocoti maña coaijë } \\
\text { daiyë iñanquë }\end{array}$ & $\begin{array}{l}\text { Veja eles trazendo o cipó de yoco } \\
\text { (A "gente vivente" pergunta para os meninos airo-pai se eles estão } \\
\text { vendo como se toma o yoco para trabalhar juntos. O aconselhamen- } \\
\text { to agora está terminando. A "gente vivente" fala para os meninos: } \\
\text { "isso é o que vocês devem ver") }\end{array}$ \\
\hline 25 & $\begin{array}{l}\text { Iye mañare cuatsaye } \\
\text { paicua }\end{array}$ & Pense assim para viver bem \\
\hline 26 & $\begin{array}{l}\text { Cuatsajë ma penoa } \\
\text { maña jejejë paicua }\end{array}$ & $\begin{array}{l}\text { Pense em pintar seu rosto de vermelho para trabalhar } \\
\text { (A "gente vivente" aconselha os menino airo-pai a enfeitarem seus } \\
\text { rostos com urucum para trabalharem bem) }\end{array}$ \\
\hline 27 & $\begin{array}{l}\text { Corotan campo tëca } \\
\text { coaijë poquërë manca }\end{array}$ & $\begin{array}{l}\text { Trazemos os pilares de madeira da casa } \\
\text { (A "gente vivente" mostra como se carregam os paus pesados em } \\
\text { grupo, todos juntos. Assim se conseguem carregar com alegria e } \\
\text { facilidade) }\end{array}$ \\
\hline
\end{tabular}




\begin{tabular}{|c|c|c|}
\hline 28 & $\begin{array}{l}\text { Iye maña cuatsajë } \\
\text { paicua umu joyaë } \\
\text { manca }\end{array}$ & $\begin{array}{l}\text { Pense assim, pequeno criado pelo japu } \\
\text { (A "gente vivente" chama os meninos airo-pai de "crias do japu"; } \\
\text { para eles, os meninos são os aprendizes do japu) }\end{array}$ \\
\hline 29 & $\begin{array}{l}\text { Cuine yeque maña } \\
\text { iñajë duto }\end{array}$ & $\begin{array}{l}\text { Veja outro caminho } \\
\text { (A "gente vivente" leva os meninos airo-pai para ver outro lugar) }\end{array}$ \\
\hline 30 & $\begin{array}{l}\text { Cucuhuasi maña } \\
\text { pujeni }\end{array}$ & $\begin{array}{l}\text { Colocando os nossos cocares } \\
\text { (A "gente vivente" se apronta para trabalhar juntos, tecendo senta- } \\
\text { dos) }\end{array}$ \\
\hline 31 & $\begin{array}{l}\text { Yequë dodo huea } \\
\text { maña tëojëé duye }\end{array}$ & Tecendo os nossos cestos de fibra sentados \\
\hline 32 & $\begin{array}{l}\text { Yeque tëhui se ponëni } \\
\text { iãto jaëpa maña tëojë } \\
\text { duye }\end{array}$ & $\begin{array}{l}\text { Do outro lado da maloca, outras pessoas estão fazendo leques sentados } \\
\text { (A "gente vivente" aconselha os meninos airo-pai a fazerem os ces- } \\
\text { tos para carregar os produtos das roças, e os leques para acender o } \\
\text { fogo e cozinhar dentro da casa) }\end{array}$ \\
\hline 33 & Paico paipi tëojë duye & "Gente vivente" tecendo sentados \\
\hline 34 & $\begin{array}{l}\text { Iye mañare cuatsajë } \\
\text { ducua }\end{array}$ & $\begin{array}{l}\text { Pense assim sentado } \\
\text { (A "gente vivente" aconselha os menino airo-pai a fazerem todos } \\
\text { esses tecidos sentados juntos) }\end{array}$ \\
\hline 35 & $\begin{array}{l}\text { Yequë maña jacona } \\
\text { tintajë duye nëca } \\
\text { daijë }\end{array}$ & $\begin{array}{l}\text { Chegamos até a nossa mãe de pé } \\
\text { (A "gente vivente" chama a casa que eles constroem de "nossa mãe") }\end{array}$ \\
\hline 36 & $\begin{array}{l}\text { Yequë maña jacopi } \\
\text { maye canihuë sëtea } \\
\text { jadude }\end{array}$ & $\begin{array}{l}\text { A pele de nossa mãe está vermelha sentada } \\
\text { (A "gente vivente" diz que a pele da casa está vermelha porque as } \\
\text { folhas do teto estão novas) }\end{array}$ \\
\hline 37 & $\begin{array}{l}\text { Cuaipë pare mañare } \\
\text { jejeë jadude }\end{array}$ & $\begin{array}{l}\text { Ela coloca pintura vermelha sentada } \\
\text { (A "gente vivente" diz que a casa está se enfeitando com urucum } \\
\text { porque o tecido de folhas do teto da casa está pintado com urucum) }\end{array}$ \\
\hline 38 & $\begin{array}{l}\text { Yuyo maña setë ja- } \\
\text { dude }\end{array}$ & $\begin{array}{l}\text { Ela coloca seus colares sentada } \\
\text { (A "gente vivente" diz que a casa está se enfeitando com os colares, } \\
\text { que são os tecidos das folhas do teto) }\end{array}$ \\
\hline 39 & $\begin{array}{l}\text { Paico jacopi huëri } \\
\text { nëcade }\end{array}$ & $\begin{array}{l}\text { Mãe vivente acorda de pé } \\
\text { (A "gente vivente" fala que a casa é uma mãe que acorda de pé por- } \\
\text { que ela faz a gente acordar, ficar de pé e trabalharmos juntos. Ela é } \\
\text { nossa mãe que nos guia, nos ensina a trabalhar juntos e tranquilos) }\end{array}$ \\
\hline 40 & $\begin{array}{l}\text { Cua'”e manca se } \\
\text { huëri nëcade }\end{array}$ & Cheia de pensamentos com bons propósitos, acorda de pé \\
\hline 41 & $\begin{array}{l}\text { Paico ponsë mañapi } \\
\text { daijë }\end{array}$ & Nós, os jovens viventes, chegamos \\
\hline 42 & Iñanque yure & $\begin{array}{l}\text { Veja isso agora } \\
\text { (A "gente vivente" diz para os meninos airo-pai verem tudo aquilo } \\
\text { que é falado no canto) }\end{array}$ \\
\hline
\end{tabular}

